\title{
Editorial
}

Tijdschr Urol (2021) 11:20

https://doi.org/10.1007/s13629-020-00314-7

Q

Check for
updates

\section{RETRACTED ARTICLE: Altijd op zoek naar beter}

\author{
Henk G. van der Poel
}

Published online: 21 October 2020

(C) The Author(s) 2020

De hoofdredacteur heeft dit editorial [1] ingetrokken. In het editorial wordt verwezen naar een aantal artikelen dat door omstandigheden niet in dit nummer is gepubliceerd. De inhoud van dit editorial klopt daarom niet meer. Er is een vervangend editorial gepubliceerd [2].

De online versie van dit artikel bevat de volledige tekst van het ingetrokken artikel als aanvullende informatie.

\section{Literatuur}

[1] van der Poel, H.G. Altijd op zoek naar beter. Tijdschr Urol (2020). https://doi.org/10.1007/s13629020-00314-7

[2] van der Poel, H.G. Tijdschr Urol (2020). https:// doi.org/10.1007/s13629-020-00315-6.
Open Access This article is distributed under the terms of the Creative Commons Attribution 4.0 International License (http://creativecommons.org/licenses/by/4.0/), which permits unrestricted use, distribution, and reproduction in any medium, provided you give appropriate credit to the original author(s) and the source, provide a link to the Creative Commons license, and indicate if changes were made.

dr. Henk G. van der Poel, hoofdredacteur 